\title{
The effect of light and nutrients on algal food quality and their consequent effect on grazer growth in subtropical streams
}

\author{
Fen Guo ${ }^{1,2,4}$, Martin J. Kainz ${ }^{3,5}$, Dominic Valdez ${ }^{1,6}$, Fran Sheldon ${ }^{1,7}$, and Stuart E. Bunn ${ }^{1,8}$ \\ ${ }^{1}$ Australian Rivers Institute, Griffith University, 170 Kessels Road, Nathan QLD 4111, Australia \\ ${ }^{2}$ State Key Laboratory of Environmental Criteria and Risk Assessment, Chinese Research Academy of Environmental Sciences, \\ 8 Dayangfang, Beiyuan, Anwai, Beijing 100012, People's Republic of China \\ ${ }^{3}$ WasserCluster Lunz - Interuniversity Centre for Aquatic Ecosystem Research, Dr. Carl Kupelwieser Promenade 5, \\ A-3293 Lunz am See, Austria
}

\begin{abstract}
Recent investigators have emphasized that food quality has greater importance than food quantity for herbivore somatic growth. Herbivore growth is thought to be regulated by light and nutrients through changes in food elemental ratios, but our knowledge of the mechanisms driving grazer growth in stream ecosystems is scarce. We manipulated light (through shading) and nutrients (fertilizer addition) in 3 headwater streams in southeastern Queensland, Australia, and measured the responses of natural grazer communities. The growth responses of Austrophlebioides and Helicopsyche to light and nutrients differed with their body size and periphyton food quality. Large larvae were more sensitive to increased light and nutrient availability than were small larvae. Light induced a significant negative effect on Austrophlebioides growth, and this impact increased with increasing nutrient addition. Nutrients had a pronounced positive effect on Helicopsyche growth regardless of light intensity. These responses reflected changes in food quality. Periphyton food quality in terms of $\mathrm{C}: \mathrm{N}$ played a more decisive role in grazer growth than algal food quantity (as chlorophyll $a$ ). The growth of large larvae was significantly greater under low light intensity and nutrient-enriched conditions where high-quality food was more abundant than under high-light and low-nutrient conditions where periphyton food quality was low. Our results suggest that changes in riparian vegetation or nutrient inputs can significantly influence grazer growth through changes in periphyton $\mathrm{C}: \mathrm{N}$. We recommend that future investigators of foodweb responses to riparian canopy change or nutrient enrichment on stream ecosystems pay more attention to the effects of algal food quality rather than quantity.
\end{abstract}

Key words: food quality, $\mathrm{C}: \mathrm{N}$ ratio, food quantity, grazers, stoichiometry, riparian canopy

Herbivores transfer energy from basal food sources to higher trophic levels (Allan and Castillo 2007). Their somatic growth and reproduction is limited by food quantity and quality (Cross et al. 2003). Measures of food quantity, e.g., primary productivity, biomass, and chlorophyll $a(\operatorname{chl} a)$, have been used widely to assess herbivore growth and biomass. However, food quantity alone is insufficient for describing the resource base of consumers in many situations (Stelzer and Lamberti 2002), and the importance of food quality for herbivores is now recognized (Sterner and Elser 2002). Stoichiometric theory proposes that the elemental imbalance between consumers and food sources reflects the degree of nutrient constraint on consumers and, thus, indicates food quality (Sterner and Elser 2002). Aquatic consumers often have lower $C$ : nutrient ratios than their food. If food elemental ratios resemble those of consumers, food is more easily assimilated because the expenditure of energy to maintain consumer elemental homeostasis is reduced. Therefore, food with low $\mathrm{C}: \mathrm{N}$ and $\mathrm{C}: \mathrm{P}$ ratios is considered to be of high quality for the consumer (Sterner and Elser 2002, Lau et al. 2008).

In benthic habitats, invertebrate grazers often are exposed to suboptimal nutritional conditions (Liess and Hillebrand 2005, Liess et al. 2009). The nutritional quality of periphyton varies with environmental conditions (Kahlert et al. 2002, Guo et al. 2016b), so the stoichiometric imbalance between algae and grazers often limits grazer growth (Fink et al. 2006, Lau et al. 2009, Ohta et al. 2011). To deal with low-quality food, grazers may alter their behavior and life history (Elser et al. 2000, Fink and Von Elert 2006, Liess 2014, Mooney et al. 2016), which may consequently affect their population dynamics, the fitness of secondary consumers, and 
nutrient cycling in benthic ecosystems (Covich et al. 1999, McManamay et al. 2011, Liess 2014). Therefore, exploration of the factors affecting algal elemental ratios and their consequences for invertebrate grazer growth is needed to untangle some of the mechanisms that underlie ecosystem processes.

Light intensity and nutrient availability are considered the 2 most important factors determining algal elemental ratios (light: nutrient hypothesis [LNH]; Sterner et al. 1997). Algae obtain $\mathrm{C}$ by photosynthesis and take up $\mathrm{N}$ and $\mathrm{P}$ from their surroundings. Increased light intensity can reduce algal $C$ : nutrient ratios under nutrient-limited conditions because it can increase algal C-fixation rates (Sterner et al. 1997). Herbivore growth is expected be highest at intermediate light-to-nutrient ratios where high-quality food is abundant. In contrast, grazer growth is expected to be nutrient limited at high light-to-nutrient ratios and $\mathrm{C}$ limited at low light-to-nutrient ratios (Urabe and Sterner 1996, Sterner et al. 1997). This expectation has generally been supported for lakes (Urabe and Sterner 1996, Hessen et al. 2002, Hillebrand et al. 2004, Qin et al. 2007), but results are contradictory in stream ecosystems. In one experimental study in oligotrophic streams, snail growth and reproduction were maximized at intermediate light intensity (Ohta et al. 2011), whereas in a field study, snail growth was driven mainly by periphyton production (Hill et al. 2010). Further, low light intensity can reduce mayfly and tadpole growth (Fuller et al. 1986, Mallory and Richardson 2005) but can increase the growth of some snail grazers (Liess and Lange 2011). In addition, algal elemental composition often tracks dissolved nutrients in streams (Stelzer and Lamberti 2001, Liess et al. 2012). Thus, shifts in stream nutrient status may directly affect benthic algal nutrient composition, which in turn influences grazer growth and density (Liess et al. 2012, Baggett et al. 2013). In natural streams, algal elemental ratios and grazer growth often are affected simultaneously by light and nutrients. Differing results between experiments and field surveys suggest that grazer growth in streams also may be influenced by factors other than food quality or by complex interactions between food quality and these other factors.

Snail grazers were the main model organisms in stream LNH studies, but how other invertebrate grazers respond to different light-to-nutrient conditions is still poorly understood. Further, invertebrate grazers may respond differently to light and nutrients, depending on their body size. Large larvae within a species of stream invertebrates are more easily affected by environmental changes than are small larvae (Bourassa and Morin 1995, Davis et al. 2010). Thus, field surveys including many different grazer species and explicit data on body size are required to elucidate the importance of LNH in natural streams, and improve our understanding of the combined effect of light and nutrients on grazer growth.

Our main objective was to assess the combined effect of light and nutrients on algal elemental ratios and their con- sequent effect on invertebrate grazer growth. In southeastern Queensland, Australia, light and nutrients are the 2 most important factors affecting in-stream algal production (Mosisch et al. 2001) and nutritional quality (Guo et al. 2015). We manipulated light and nutrients in 3 headwater streams containing natural grazer communities to test the following hypotheses: 1) grazer growth is higher at low light : nutrient ratios where algal elemental ratios decrease and lower at high light: nutrient ratios where algal elemental ratios increase; 2) grazer responses to different light : nutrient conditions vary with grazer species identity and body size because large larvae are more sensitive to changes in light and nutrient regimes than are small larvae of the same species.

\section{METHODS}

\section{Study streams}

Our study was conducted in the upper Mary River catchment in southeastern Queensland (lat $152^{\circ} 40^{\prime} \mathrm{E}$, long $26^{\circ} 45^{\prime} \mathrm{S}$ ) in 3 headwater streams (Table 1) without direct human disturbance on study reaches or upstream catchments. These streams typically are at base flow from July to October, and most rainfall occurs from December to March (Guo et al. 2016a). The major land use in this region is forestry, and most agriculture involves cattle grazing on the lower slopes and in the surrounding lowland areas (Bunn et al. 1999). $\mathrm{N}$ (rather than $\mathrm{P}$ ) is the primary limiting nutrient for algal growth in this area (Mosisch et al. 2001, Udy et al. 2006). The experiment was carried out for 6 wk between September and November 2013. No major rainfall events occurred during this period, and streams remained at baseflow conditions throughout the experiment.

\section{Experimental design}

Two light levels (open and shade canopy) and 2 nutrient regimes (ambient and enriched) were applied in a $2 \times 2$ factorial design in each of the 3 streams. Periphyton, macroinvertebrates, and water-column nutrient samples were collected on the first (pretreatment: day 0) and last (posttreatment: day 42) days of the experiment. Treatment effects were measured as changes in periphyton $\mathrm{C}: \mathrm{N}$ ratio, $\operatorname{chl} a$, grazer head width or density from pre- to posttreatment periods.

\section{Experimental treatments}

The open-canopy $(\mathrm{O})$ treatment represented high light: nutrient conditions, and the shade-canopy plus added nutrients $(\mathrm{S}+\mathrm{N})$ treatment represented low light : nutrient conditions. The shade-canopy (S) and the open-canopy plus added nutrients $(\mathrm{O}+\mathrm{N})$ treatments represented intermediate light: nutrient conditions. Treatments without nutrient addition $(\mathrm{O}$ and $\mathrm{S})$ were always situated upstream from nutrientaddition treatments $(\mathrm{O}+\mathrm{N}$ and $\mathrm{S}+\mathrm{N})$ and were separated from them by $\geq 15 \mathrm{~m}$. In each stream, 4 riffles with open canopy cover were selected. Each treatment was situated in a riffle dominated by cobble substrate, and the sampling 


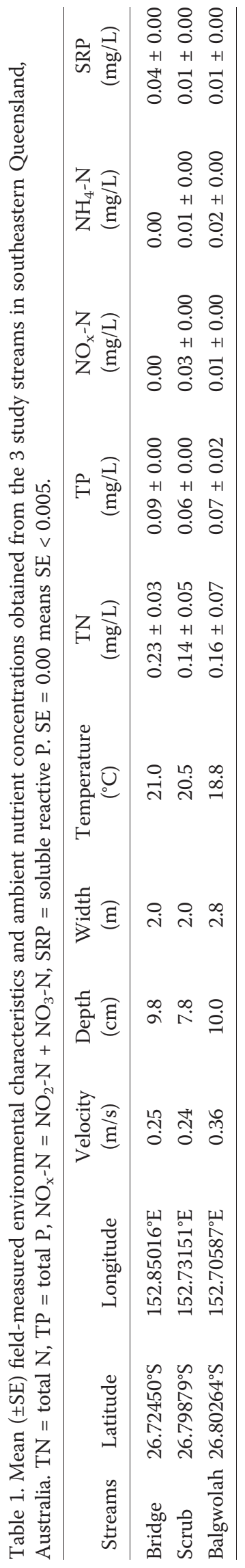


area for each treatment ranged from 4.50 to $6.08 \mathrm{~m}^{2}$. Light availability was measured by photographing the riparian canopy in mid-stream 50 to $100 \mathrm{~cm}$ above the water surface at each potential study riffle with a Nikon D70 camera (Nikon Corporation, Tokyo, Japan) and a fish-eye lens. Images were analyzed with Gap Light Analyzer (version 2; Simon Fraser University, Burnaby, British Columbia, and the Institute of Ecosystem Studies, Millbrook, New York; Frazer et al. 1999) to extract forest canopy and gap light transmission indices. Only riffles with riparian canopy cover $\leq 20 \%$ were used for this study. Shade cloth with $90 \%$ shading effects was suspended from steel posts $\sim 0.5$ to $1.0 \mathrm{~m}$ from the water surface to obtain the shaded canopy.

Nutrient enrichment was accomplished by installing stockings (made of the same shade cloth) filled with fertilizer pellets (Osmocote Exact Standard 3-4 months, slow diffusing; Scotts Australia, Bella Vista, Australia) upstream of the study reaches. About $500 \mathrm{~g} / \mathrm{m}^{2}$ fertilizer was added, which can release $0.45 \mathrm{~g} \mathrm{~N}$ and $0.11 \mathrm{~g} \mathrm{P} \mathrm{m}^{-2} \mathrm{~d}^{-1}$ for $56 \mathrm{~d}$. This value was calculated according to the Redfield ratios (Redfield 1958) needed to support gross primary production of $3000 \mathrm{mg} \mathrm{C} \mathrm{m}^{-2} \mathrm{~d}^{-1}$ in cobble streams in southeastern Queensland (Udy and Bunn 2001).

\section{Sample collection}

Invertebrate grazers Macroinvertebrates were collected from a $30-\times 30-\mathrm{cm}$ quadrat. All cobbles in the quadrat were picked, and macroinvertebrates clinging to the cobbles were washed into a white tray. Three quadrats were sampled in each treatment. Cased and free-living caddisflies were separated, mayflies were identified to family, and other invertebrates were sorted to order by eye. The main invertebrate grazers in this area were mayflies and caddisflies (McKenny 2005), and specimens in these orders were preserved in liquid $\mathrm{N}$ in the field and placed at $-80^{\circ} \mathrm{C}$ in the laboratory until further analysis.

Periphyton The same cobbles were used to collect periphyton samples for elemental content and biomass analysis. In each experimental unit, 4 replicate periphyton samples for elemental analysis were scraped with brushes from cobbles into distilled water. The resulting algal slurry was collected and stored in a portable freezer in the field and at $-20^{\circ} \mathrm{C}$ in the laboratory. In each experimental unit, 3 replicate samples were collected for $\operatorname{chl} a$ analysis by placing a circular ring (area: $13.2 \mathrm{~cm}^{2}$ ) on the surface of a cobble and sampling the periphyton within the ring. The resulting algal slurry was filtered onto 47-mm Whatman GF/F filters and covered with $\mathrm{Al}$ foil. Samples were immediately placed in liquid $\mathrm{N}$ and later stored at $-80^{\circ} \mathrm{C}$ in the laboratory. All samples were processed within $1 \mathrm{wk}$ of collection.

Physicochemical variables Water samples were collected to assess total $\mathrm{N}(\mathrm{TN}), \mathrm{NO}_{3}+\mathrm{NO}_{2}\left(\mathrm{NO}_{\mathrm{x}}-\mathrm{N}\right), \mathrm{NH}_{4}-\mathrm{N}$, total $\mathrm{P}$
(TP), and soluble reactive P (SRP). Samples were stored in a portable freezer in the field and placed at $-20^{\circ} \mathrm{C}$ in the laboratory. Samples were processed within 2 wk. Temperature, conductivity, and $\mathrm{pH}$ were measured with a portable turbidity meter (model WP-88; TPS Pty Ltd, Brisbane, Australia) (Table 1). Current velocity was measured with a current velocity meter (model 2100; Swoffer Instruments, Seattle, Washington) (Table 1). Water depth and width were measured with a measuring tape (Table 1).

\section{Sample processing}

Invertebrate grazers Mayflies and caddisflies were freezedried and identified to genus with the aid of a dissecting microscope. All macroinvertebrates were classified into functional feeding groups (Cummins and Klug 1979). Grazers found in the study streams included the mayfly Austrophlebioides and the caddisflies Helicopsyche, Agapetus, and Tasimi. The most abundant grazers, Austrophlebioides (1110 individuals) and Helicopsyche (462 individuals), accounted for $>75 \%$ of the grazer abundance and were present in all streams. The head-capsule width of all individuals of these 2 grazers was measured with the aid of an eyepiece micrometer, and their density in each treatment was recorded. The head width of Austrophlebioides ranged from 0.75 to $2.50 \mathrm{~mm}$ and for Helicopsyche 0.25 to $0.90 \mathrm{~mm}$.

Periphyton Periphyton samples for elemental analysis were oven-dried at $60^{\circ} \mathrm{C}$ for $60 \mathrm{~h}$ until completely dry, and all dried samples were homogenized with a mortar and pestle. Seven to eight mg of each sample was weighed into a small $\mathrm{Sn}$ capsule. Periphyton $\mathrm{C}$ and $\mathrm{N}$ contents were measured with a continuous flow-isotope ratio mass spectrometer (IRMS) (Sercon Hydra 20-22, Evroda EA-GSL; Crewe, Cheshire, UK). Algal chl $a$ extraction and spectrophotometric analysis followed Muhid et al. (2013). Filters were immersed in ice-cold $100 \%$ ethanol, sonicated twice for $30 \mathrm{~s}$ at 50/50 pulse, and the extract was placed at $-20^{\circ} \mathrm{C}$ for $24 \mathrm{~h}$. Absorbances of these extracts were measured at 750, 665, 664, 647, and $630 \mathrm{~nm}$ (Jeffrey and Humphrey 1975). The hydrochloric acid treatment was used to adjust chl $a$ values for phaeopigments (Lorenzen 1967). Chl $a$ concentration was expressed as $\mu \mathrm{g} / \mathrm{cm}^{2}$.

Physicochemical variables Dissolved nutrients $\left(\mathrm{NO}_{\mathrm{x}}-\mathrm{N}\right.$, $\mathrm{NH}_{4}-\mathrm{N}$, and SRP) were analyzed with a SmartChem 200 discrete chemical analyzer (Westco Scientific Instruments, Brookfield, Connecticut) (APHA 1995). Total nutrients (TN and TP) were digested with a simultaneous persulfate digestion method (Hosomi and Sudo 1986) before analysis on the same instrument (Table 1).

\section{Data analysis}

Linear mixed-effect models were used to detect significant changes from pre- to posttreatment periods within treat- 
ments. The response variables were periphyton $\mathrm{C}: \mathrm{N}$ ratio, chl $a$, grazer head width or density, with the period (pre- and post-treatment) as fixed factors and the 3 streams as random factors. The protocol for linear mixed model fit and validation followed Zuur et al. (2009). The restricted maximum likelihood estimation was used to fit models, and the likelihood ratio test was used to compare and select fitted models. First, 3 models were constructed: 1) a linear model based on generalized least squares (without random effect) to investigate the fixed-factor effects, 2) a mixed-effect random intercept model (with streams as random factors), and 3) a mixed-effect random intercept and slope model (considering initial conditions in each stream). The likelihood test ratio was then used to choose the best model. If assumptions of the model were not met, quadratic terms were added, or data were rank-transformed. The optimal model obtained was refitted and validated. The estimated changes of the response factors helped assess the direction and magnitude of the treatment effect.

Assignment of larvae to size classes Effects of light and nutrients on the head width and densities of 2 grazers were first assessed graphically. Increased head width without a concomitant increase in total density would imply that the treatment increased the average individual size of at least some size groups of grazers. Next, a body-size-specific analysis was conducted to assess the effects of light and nutrients on grazer size groups. Instead of assigning a single head width (i.e., an average or maximum body size) to a taxon, each individual was assigned to an approximate size class on the basis of its $\log _{10}(x)$-transformed head width. A linear mixed-effect model was used to compare the differences in each size group in each treatment between the pre- and posttreatment periods. This calculation was repeated for the head widths within each size group.

This body-size analysis was conducted separately for 2 grazers. Large larvae of Austrophlebioides $(\geq 2.0 \mathrm{~mm})$ and Helicopsyche $(\geq 0.65 \mathrm{~mm})$ were grouped into a size category that provided a sufficient sample size for analysis. The results from the linear mixed models indicated that the treatment effects varied among head-width groups. Divergences in the Austrophlebioides response were detected at a size class of $1.7 \mathrm{~mm}$ and in Helicopsyche at $0.45 \mathrm{~mm}$. Each grazer was categorized into 2 representative groups: Austrophlebioides small (individual head width: $<1.7 \mathrm{~mm}$ ) and large larvae (individual head width: $\geq 1.7 \mathrm{~mm}$ ), and Helicopsyche small (individual head width: $<0.45 \mathrm{~mm}$ ) and large larvae (individual head width: $\geq 0.45 \mathrm{~mm}$ ). Then linear mixed models were used to estimate the changes in size of large and small larvae in Austrophlebioides and Helicopsyche from the pre- to posttreatment periods. The smallest size groups with the fewest individuals relative to other size groups (Austrophlebioides $0.75-1.0 \mathrm{~mm}$ and Helicopsyche $0.25-0.35 \mathrm{~mm}$ ) were collected in only 1 stream at the pretreatment stage, so they were excluded from further analysis.
Analysis of treatment effects Linear regression models were used to explore the relationships between grazer somatic growth, periphyton $\mathrm{C}: \mathrm{N}$, and algal biomass. The $\%$ changes of periphyton $\mathrm{C}: \mathrm{N}$, chl $a$, and grazer head width from day 0 to day 42 were calculated to standardize for initial conditions in each stream. The \% change of grazer head width was the response factor, and the \% change of periphyton $\mathrm{C}: \mathrm{N}$ or biomass was the predictor, respectively. Data were $\log _{10}(x)$-transformed to approximate a normal distribution. An information-theoretic approach was used for model selection (Johnson and Omland 2004). A likelihood ratio test was used to assess each model relative to a null model. The top models were selected by ranking models using the small sample unbiased Akaike information criterion (AICc) with the cut-off rule $\triangle \mathrm{AICc}$ $\leq 2$ (Burnham and Anderson 2001). Model averaging was used to produce 1 final model, and "0 method" was used to estimate regression coefficients (Burnham and Anderson 2002). All analyses were done in the $R$ environment (version 3.0.3; R Project for Statistical Computing, Vienna, Austria), using the extension package lme4 for linear mixedeffect models (Bates et al. 2012), and the package MuMIn for model selection and model averaging (Bartoń 2009).

\section{RESULTS}

\section{Periphyton}

Periphyton $\mathrm{C}: \mathrm{N}$ and $\mathrm{chl} a$ varied with light: nutrient ratio conditions (Table $\mathrm{S} 1$, Table 2). In the $\mathrm{O}$ treatment, periphyton $\mathrm{C}: \mathrm{N}$ increased significantly, whereas periphyton $\mathrm{C}: \mathrm{N}$ did not change significantly in the $\mathrm{S}+\mathrm{N}$ treatment. In the $\mathrm{S}$ and $\mathrm{O}+\mathrm{N}$ treatments, periphyton $\mathrm{C}: \mathrm{N}$ slightly decreased but these changes were not significant. Algal biomass (as chl $a$ ) did not change significantly in response to any light : nutrient treatment.

\section{Invertebrate grazers}

Head-capsule width and density in response to light : nutrient conditions differed among grazer size groups and species (Figs 1A-F, 2A-F). Density of small Austrophlebioides increased in all treatments (Fig. 1C), and the density of small Helicopsyche decreased in the $\mathrm{O}$ treatment (Fig. 2C). Headcapsule width of small larvae of both species was unaffected by light : nutrient conditions (Figs 1F, 2F).

Head-capsule width of large Austrophlebioides (Fig. 1E) decreased in the $\mathrm{O}$ treatment, but their density did not change (Fig. 1B), indicating that somatic growth decreased. In the $\mathrm{S}+\mathrm{N}$ treatment, the average head-capsule width of large larvae increased (Fig. 1E), but their overall density did not change, indicating an increase in somatic growth. In the $\mathrm{S}$ treatment, overall larval density (Fig. 1A), density of large larvae (Fig. 1B), and the average head-capsule width of large larvae increased (Fig. 1E), indicating that large larvae grew even larger, and more large larvae moved into the surveyed area from other areas, whereas in the $\mathrm{O}+\mathrm{N}$ treatment, 
Table 2. Mean $( \pm \mathrm{SE})$ periphyton $\mathrm{C}: \mathrm{N}$ and chlorophyll $a(\mathrm{chl} a)$ in 4 treatments and the change from pretreatment (day 0$)$ to posttreatment (day 42) were tested with linear mixed-effect models. The estimated changes in periphyton $\mathrm{C}: \mathrm{N}$ ratios and chl $a$ were calculated based on the $\log _{10}(x)$-transformed data. Periphyton $C: N$ and chl $a$ were used as the response factors, with period (pre- and posttreatment) as fixed factor and streams as random factors. Data were $\log _{10}(x)$-transformed for normal distribution approximation. Model fit and validation protocols followed Zuur et al. (2009). * indicates a significant difference from pre- to posttreatment period $(p<0.05)$

\begin{tabular}{llccrrr}
\hline \multicolumn{1}{c}{ Variable } & \multicolumn{1}{c}{ Treatment } & Pretreatment & Posttreatment & Change & $F$ & $p$ \\
\hline $\mathrm{C}: \mathrm{N}$ ratio & Open (O) & $7.55 \pm 0.62$ & $8.22 \pm 0.45$ & $0.03 \pm 0.01$ & 5.94 & $\mathbf{0 . 0 2}$ \\
& Open + nutrients $(\mathrm{O}+\mathrm{N})$ & $9.58 \pm 2.51$ & $7.96 \pm 0.49$ & $-0.02 \pm 0.09$ & 0.06 & 0.76 \\
& Shade (S) & $8.27 \pm 1.54$ & $7.75 \pm 0.38$ & $-0.01 \pm 0.08$ & 0.01 & 0.89 \\
& Shade + nutrients (S+N) & $8.72 \pm 1.21$ & $7.71 \pm 0.29$ & $-0.00 \pm 0.06$ & 0.01 & 0.89 \\
$\mathrm{Chl} a\left(\mu \mathrm{g} / \mathrm{cm}^{2}\right)$ & Open (O) & $0.89 \pm 0.54$ & $0.90 \pm 0.44$ & $0.16 \pm 0.21$ & 0.57 & 0.39 \\
& Open + nutrients (O+N) & $0.61 \pm 0.40$ & $0.42 \pm 0.21$ & $-0.01 \pm 0.13$ & 0.01 & 0.96 \\
& Shade (S) & $1.41 \pm 1.33$ & $0.41 \pm 0.19$ & $-0.21 \pm 0.39$ & 0.29 & 0.54 \\
& Shade + nutrients (S+N) & $0.41 \pm 0.25$ & $0.65 \pm 0.41$ & $0.21 \pm 0.01$ & 3.56 & 0.06 \\
\hline
\end{tabular}

larval density and head-capsule width of large larvae did not change (Fig 1B, E).

The density and head-capsule width of large Helicopsyche (Fig. 2B, E) did not change in the $\mathrm{O}$ treatment, whereas in the $\mathrm{S}+\mathrm{N}$ treatment, their density did not change but headcapsule width increased, which suggested they grew bigger. In the $\mathrm{S}$ treatment, the density and head width of large larvae did not change, whereas in the $\mathrm{O}+\mathrm{N}$ treatment, their den-
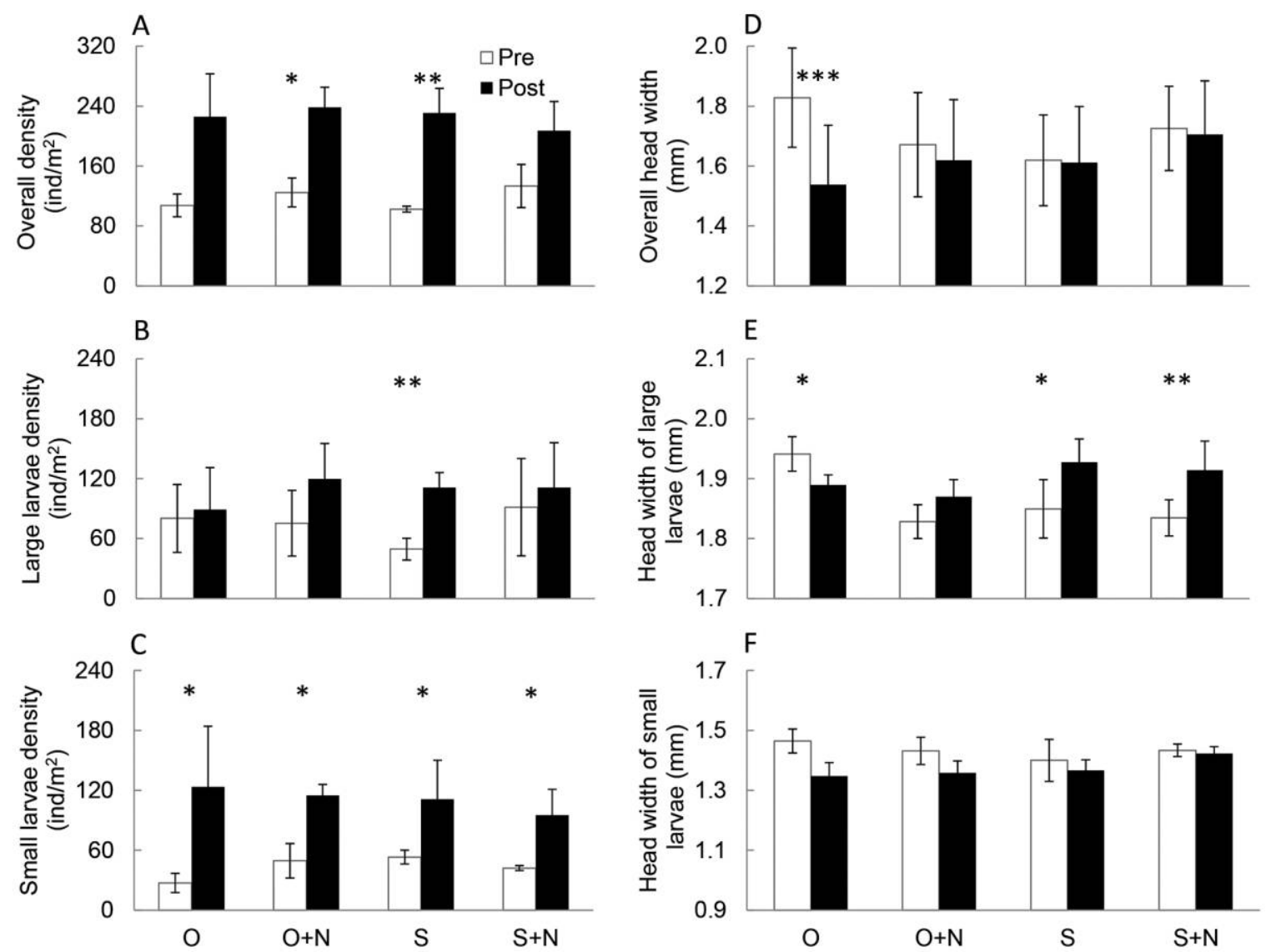

Figure 1. Mean $( \pm$ SE) density $(\mathrm{A}-\mathrm{C})$ and head width $(\mathrm{D}-\mathrm{F})$ of all $(\mathrm{A}, \mathrm{D})$, large $(\mathrm{B}, \mathrm{E})$, and small $(\mathrm{C}, \mathrm{F})$ Austrophlebioides larvae in the pre- and posttreatment periods (Pre and Post, respectively). $\mathrm{O}=$ high light : nutrient conditions (open canopy), $\mathrm{O}+\mathrm{N}=$ intermediate light : nutrient conditions (open canopy and added nutrients), $\mathrm{S}=$ intermediate light : nutrient conditions (shade canopy), $\mathrm{S}+\mathrm{N}=$ low light : nutrient conditions (shade canopy and added nutrients). ${ }^{*} p<0.05,{ }^{* * *} p<0.01,{ }^{* * * * *} p<0.001$. Ind $=$ individuals. 

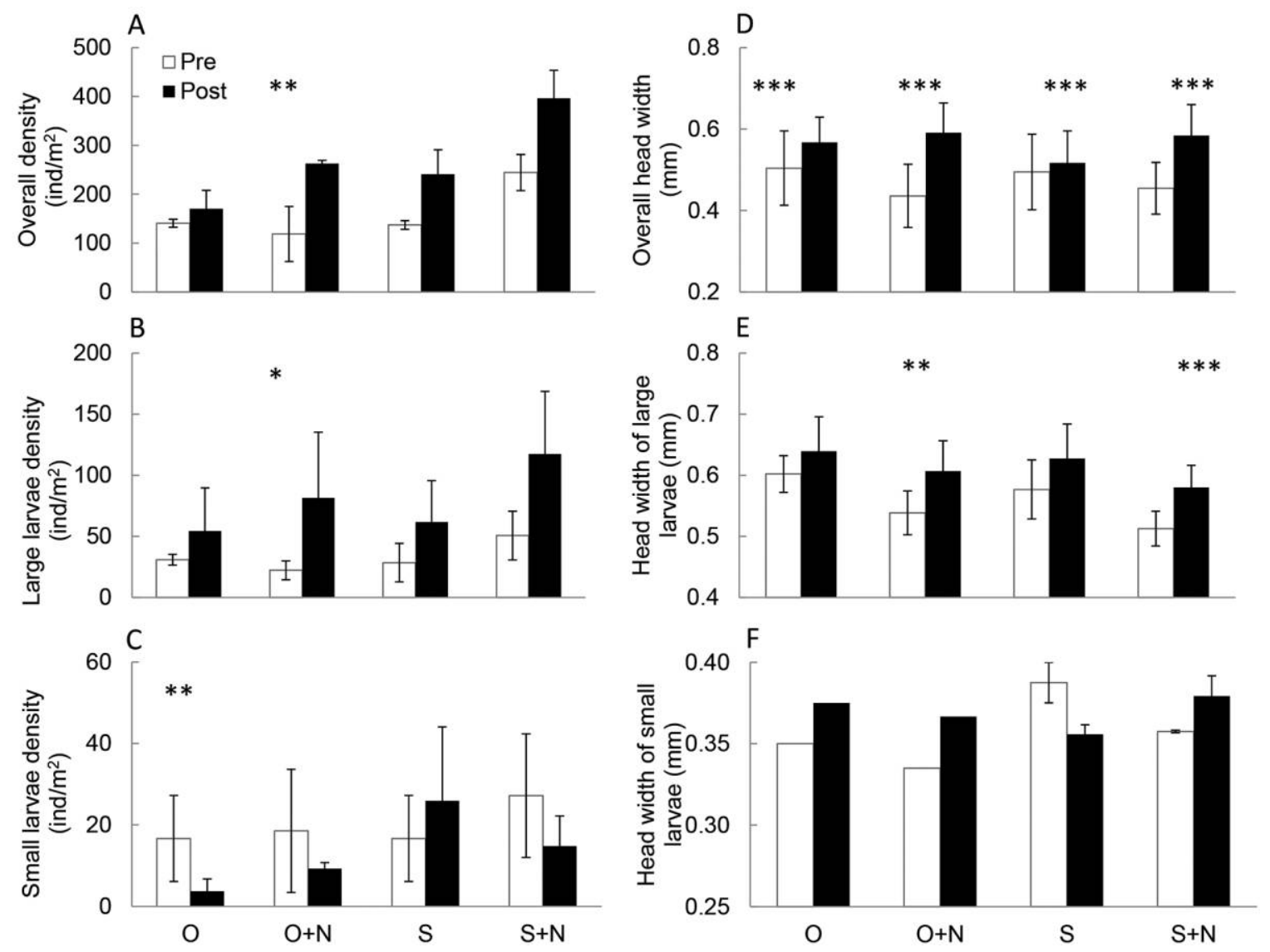

Figure 2. Mean $( \pm \mathrm{SE})$ density $(\mathrm{A}-\mathrm{C})$ and head width $(\mathrm{D}-\mathrm{F})$ of all $(\mathrm{A}, \mathrm{D})$, large $(\mathrm{B}, \mathrm{E})$, and small $(\mathrm{C}, \mathrm{F})$ Helicopsyche larvae in the pre- and posttreatment periods (Pre and Post, respectively). $\mathrm{O}=$ high light : nutrient conditions (open canopy), $\mathrm{O}+\mathrm{N}=$ intermediate light : nutrient conditions (open canopy and added nutrients), $\mathrm{S}=$ intermediate light : nutrient conditions (shade canopy), $\mathrm{S}+\mathrm{N}=$ low light : nutrient conditions (shade canopy and added nutrients). ${ }^{*} p<0.05, * * p<0.01,{ }^{* * * *} p<0.001$. Ind = individuals.

sity and head-capsule width both increased, suggesting that large larvae grew even larger, and more large larvae moved into the surveyed area from other areas.

The growth patterns of only large larvae were used for the linear regression analysis because only large larvae were affected by the light: nutrient treatments. The change in periphyton $\mathrm{C}: \mathrm{N}$ was selected as the best-fit explanatory factor predicting the somatic growth of large larvae of both species (Table 3, Fig. 3A, B). Periphyton $\mathrm{C}: \mathrm{N}$, chl $a$, and the null model explained $\sim 77, \sim 20$, and $\sim 3 \%$ of the variation in head width of Austrophlebioides, respectively. The periphyton $\mathrm{C}: \mathrm{N}$ model $(\triangle \mathrm{AICc}=0.00)$ was selected as the best model according to the cut-off rule $\triangle \mathrm{AICc} \leq 2$. Somatic growth of large Austrophlebioides decreased with

Table 3. The small sample unbiased Akaike information criterion (AICc), $\triangle$ AICc, and Akaike weights of models in the candidate linear regression models calculated for grazer growth where each model provided a statistically better fit to the data than the null model. The percentage change of grazer head width from pre- to posttreatment (day 0-day 42) was the response variable, and that of periphyton $C: N$ ratio or biomass was the predictor form. $\mathrm{df}=\mathrm{degrees}$ of freedom, $\operatorname{logLik}=\log$ likelihood. Bold indicates the top models selected by the cut-off rule $\triangle \mathrm{AICc} \leq 2$.

\begin{tabular}{lllllcc}
\hline Response variable & Predictor form & $\mathrm{df}$ & $\operatorname{logLik}$ & AICc & $\Delta$ AICc & Weight \\
\hline Austrophlebioides & C $:$ N ratio & $\mathbf{3}$ & $\mathbf{3 3 . 3 1}$ & $\mathbf{- 5 7 . 6}$ & $\mathbf{0 . 0 0}$ & $\mathbf{0 . 7 7}$ \\
& Chl $a$ & 3 & 31.97 & -54.9 & 2.69 & 0.20 \\
Helicopsyche & Null & 2 & 28.11 & -50.9 & 6.74 & 0.03 \\
& C $:$ N ratio & $\mathbf{3}$ & $\mathbf{2 1 . 6 5}$ & $-\mathbf{3 4 . 3}$ & $\mathbf{0 . 0 0}$ & $\mathbf{0 . 7 2}$ \\
& Chl $a$ & 3 & 19.94 & -30.9 & 3.42 & 0.14 \\
& Null & 2 & 17.65 & -30.0 & 4.34 & 0.09 \\
\hline
\end{tabular}



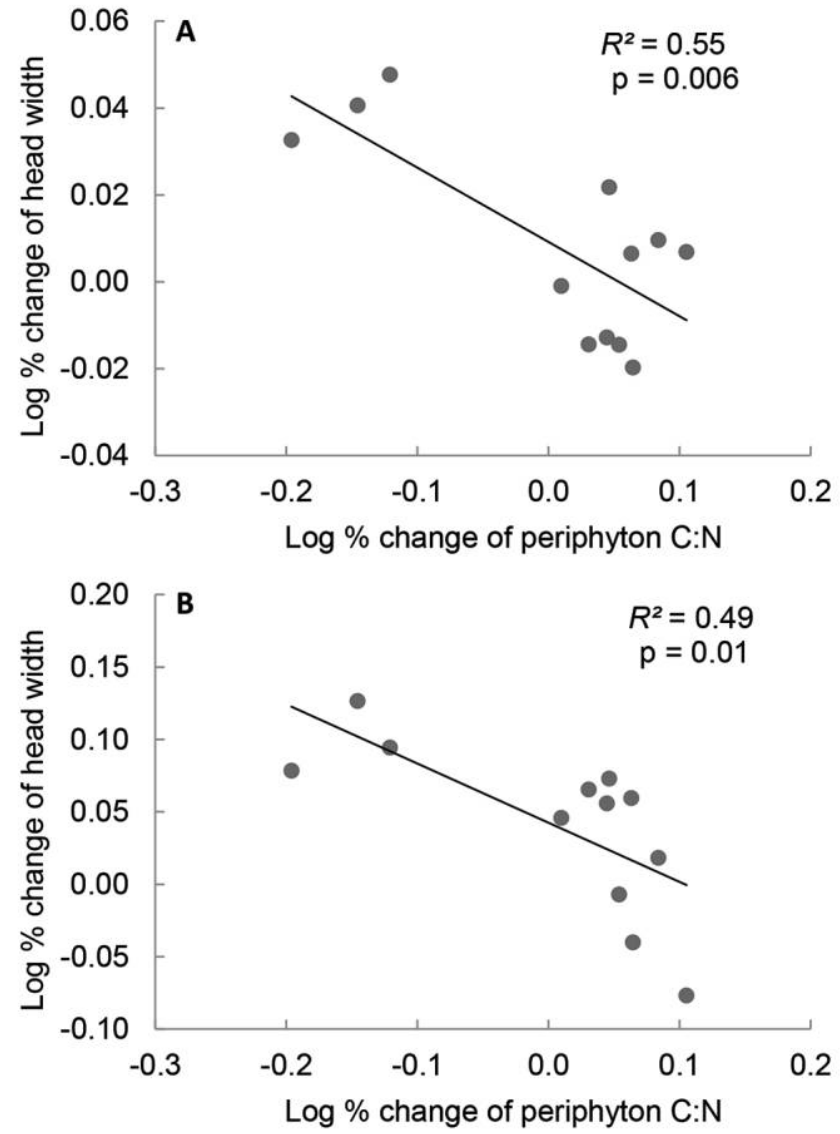

Figure 3. Relationships between $\%$ change in head-capsule width from pre- to posttreatment (day 0-day 42) of large larvae for Austrophlebioides (A) and Helicopsyche (B) and periphyton $C: N$. All data were $\log _{10}(x)$-transformed. Regression coefficients were estimated by model averaging procedure.

increasing algal $\mathrm{C}: \mathrm{N}\left(R^{2}=0.55, p=0.006\right)$, and regression coefficients were estimated by model averaging (Fig. 3A). The periphyton $\mathrm{C}: \mathrm{N}$ model $(\triangle \mathrm{AICC}=0.00)$ also was selected as the best model of somatic growth of large Helicopsyche. Periphyton $\mathrm{C}: \mathrm{N}$, chl $a$, and the null model explained $\sim 72, \sim 14$, and $\sim 9 \%$ of the variation in head width of Helicopsyche, respectively. Somatic growth of large Helicopsyche decreased with increasing periphyton $\mathrm{C}: \mathrm{N}\left(R^{2}=0.49\right.$, $p=0.01$; Fig. 3B).

\section{DISCUSSION}

Our study shows that light and nutrients affected stream grazer growth by regulating periphyton $\mathrm{C}: \mathrm{N}$ in subtropical streams, thereby providing field evidence in support of the LNH. The key grazers in the study streams, Austrophlebioides and Helicopsyche, were used for the first time in a LNH study. Their responses to light and nutrients depended on their body size and periphyton $\mathrm{C}: \mathrm{N}$. Large larvae were more sensitive to changes in light and nutrients than were small larvae, and the large larvae of Austrophlebioides and
Helicopsyche differed in their responses to light and nutrients (supporting prediction 2). Consistent with the LHN, large larvae were significantly larger on day 42 than on day 0 in the $\mathrm{S}+\mathrm{N}$ treatment (low light: nutrient conditions) and significantly smaller on day 0 than on day 42 in the $\mathrm{O}$ treatment (high light: nutrient conditions) (supporting prediction 1).

\section{Differences between large and small larvae}

Our study provides field evidence that grazer growth response to light and nutrients was stronger in large than in small larvae. The growth patterns of small larvae of both grazers were unaffected by light and nutrients, whereas those of large larvae responded to manipulated light and nutrients. This difference in growth response of differently sized larvae was similar between mobile (Austrophlebioides) and sedentary grazers (Helicopsyche). Larger invertebrates might be able to outcompete their smaller competitors for food or space (Bourassa and Morin 1995, Davis et al. 2010). When food is limited, competition among consumers can restrict growth and fecundity, and intraspecific competition is usually stronger than interspecific competition among herbivores (Gurevitch et al. 1992). The greater ability of large larvae to compete with small larvae for food may enable large larvae to enhance their growth when food quality is high. Our data indicate that the growth of large larvae may be more strongly coupled to changes in periphyton food quality than is the growth of small larvae. This conclusion is supported by the growth pattern of small larvae in our study. The head widths of small larvae of both grazer species did not differ between treatments after $42 \mathrm{~d}$ of experimental manipulation. In addition, dietary plasticity resulting from omnivory could potentially contribute to the size differences. Some detritivores consume mainly detritus during small larval stages, but switch to cannibalism and intraguild predation as large larvae (Wissinger et al. 1996). However, C stable-isotope analyses from study streams show strong correlations between large larvae and periphyton (Fig. S1). Thus, large larvae were more strongly affected than small larvae by changes in periphyton food quality induced by light and nutrients.

In previous manipulative studies exploring grazer growth in response to light and nutrients, investigators mostly used grazers in certain size groups as model organisms, such as Gyraulus chinensis with shell-diameter 3.0 to $3.2 \mathrm{~mm}$ (Ohta et al. 2011), Potamopyrgus antipodarum with 2 to $3 \mathrm{~mm}$ in length and mean dry mass of $2.1 \mathrm{mg}$ (Liess and Lange 2011), and Elimia clavaeformis ranging from 20 to $150 \mathrm{mg}$ (Hill et al. 2010). Growth rates are easier to observe and compare when using similar size classes in various treatments. Nevertheless, this approach may lead to neglect of some other size classes that might have important functional roles in streams and further alter aquatic ecosystem functions (Davis et al. 2010). In our study, large and small 
larvae differed in their responses to manipulated light and nutrients. Large larvae are discussed below because only large larvae were significantly affected by light and nutrients.

\section{Grazer response to different light and nutrient conditions}

Periphyton $\mathrm{C}: \mathrm{N}$ rather than biomass (as chl $a$ ) was selected as the best-fit explanatory variable for grazer growth. Increasing algal $\mathrm{C}: \mathrm{N}$ predicted decreasing grazer growth, a result suggesting that periphyton food quality played a more important role in stream grazer growth than food quantity. High light : nutrient conditions $(\mathrm{O})$ induced high periphyton $\mathrm{C}: \mathrm{N}$ and a pronounced decrease in the head width of large larvae of Austrophlebioides compared to the other experimental treatments, which suggested that grazer growth was strongly constrained by food quality (periphyton $\mathrm{C}: \mathrm{N}$ ). This result is in agreement with the $\mathrm{LNH}$, which postulates that herbivore growth rates are more likely to be limited by food quality in environments with high light: nutrient ratios (Sterner et al. 1997).

In contrast, low light: nutrient conditions $(\mathrm{S}+\mathrm{N})$ induced an increase in head-capsule width of both grazers relative to initial conditions (i.e., growth). Fertilizer addition caused periphyton $\mathrm{C}: \mathrm{N}$ to decrease slightly but not significantly. This result could have been caused by increased grazing activity. Grazers selectively remove nutrientrich patches by direct consumption (Butler et al. 1989, Cross et al. 2005), but also spend more time in nutrient-rich patches than would be expected under random movement (Hart 1981, Kohler 1984). On the other hand, periphyton food quantity would be enhanced by added nutrients (Mosisch et al. 2001). Results of a recent field study, in which the importance of food quantity over quality for grazer growth was emphasized, suggested that grazers were $C$ limited (Hill et al. 2010). However, in our study, all reaches were initially under open canopy $(\leq 20 \%)$ and received enough sunlight to support algal growth. Thus, food availability was relatively high. Moreover, algal chl $a$ did not change relative to initial conditions in any treatment, a result indicating that food quantity was not limited. When food quantity is high, stream grazers should have enough $\mathrm{C}$ for metabolism and somatic growth, so other essential nutrients, e.g., $\mathrm{N}$ in our study, would constrain their growth (Stelzer and Lamberti 2002). Our results suggest that periphyton food quality $(\mathrm{C}: \mathrm{N})$ was the primary regulator of somatic growth of the grazers in our study.

The responses of Austrophlebioides and Helicopsyche to light and nutrients differed between the 2 intermediate light: nutrient conditions $(\mathrm{S}$ and $\mathrm{O}+\mathrm{N})$. In the $\mathrm{S}$ treatment, size and density of Austrophlebioides increased significantly, whereas those of Helicopsyche did not change. The Austrophlebioides result is in accordance with results of a previous study where grazer growth increased in response to shading (Liess and Lange 2011). However, in their study, increased growth was not connected to higher food quality, as in our study. Liess and Lange (2011) speculated that a reduced necessity to hide from predators or high ultraviolet (UV) radiation in shaded treatments might have led to increased grazing and, thus, growth rates. Even in our study, increased growth rates of Austrophlebioides in S treatments might have had a similar case. However, in our study, the densities of small larvae increased in all treatments (Fig. 1C), a result suggesting that the effect of UV radiation or predation was not a structuring factor in our study streams. In addition, Helicopsyche was probably protected from harmful radiation by their mineral cases and, thus, did not show any growth in response to changed light intensity in the $\mathrm{S}$ compared to $\mathrm{O}$ treatment. Therefore, we conclude that the growth of Austrophlebioides in the S treatment was regulated by increased periphyton food quality.

On the other hand, in the $\mathrm{O}+\mathrm{N}$ treatment, the headcapsule width and density of Helicopsyche significantly increased, but those of Austrophlebioides did not change. Responses of Austrophlebioides and Helicopsyche were probably affected by their species-specific traits. Helicopsyche are sedentary grazers and, thus, are more strongly exposed to local changes in periphyton food quality and more able to track these changes. This conclusion is supported by previous findings that cased caddisflies are more effective periphyton grazers than mobile mayflies (Lamberti et al. 1987). The increase in density of large Helicopsyche (Fig. 2B) indicated increased periphyton food quality in the $\mathrm{O}+\mathrm{N}$ treatment, given that periphyton food quantity was not limited in study streams. Thus, in the $\mathrm{O}+\mathrm{N}$ treatment, grazer growth was mainly restricted by periphyton food quality.

Previous studies suggest that grazer nutrient limitation is widespread and important in streams. As a consequence, grazers selectively choose food sources with low $\mathrm{C}$ : nutrient ratios and transfer this dietary energy to higher trophic levels (Stelzer and Lamberti 2002, Sperfeld et al. 2012). The link between algal $\mathrm{C}: \mathrm{P}$ and grazer growth has been established in running waters (Stelzer and Lamberti 2002). In our study, only $\mathrm{C}: \mathrm{N}$ was examined because $\mathrm{N}$ was the primary limiting nutrient for algae in the study catchment (see Mosisch et al. 2001). Light- and nutrient-induced changes in periphyton $\mathrm{C}: \mathrm{N}$ were directly reflected in the growth patterns of stream grazers, with potential effects on consumers at higher trophic levels. We recommend that in future studies on the effects of riparian-canopy change or nutrient enrichment on stream ecosystems, investigators should place more attention on the effects of food quality rather than quantity.

\section{ACKNOWLEDGEMENTS}

The authors thank Associate Editor Antonia Liess and 2 anonymous referees for their valuable comments on the manuscript. The authors also thank landowners for the access to their properties and Lake Baroon Catchment Care Group for help finding proper study streams. The authors are grateful to Wei Wu, Fran- 
cisco Villamarin, Jing Lu, Juan Tao, and Carolyn Polson for assistance with sample collection and water nutrient analysis. The research was supported by a PhD grant from Griffith University to FG.

\section{LITERATURE CITED}

Allan, J. D., and M. M. Castillo. 2007. Stream ecology: structure and function of running waters. Springer Science + Business Media, Dordrecht, The Netherlands.

APHA (American Public Health Association). 1995. Standard methods for the examination of water and wastewater. American Public Health Association, American Water Works Association, Water Environment Federation, Washington, DC.

Baggett, L. P., K. L. Heck, T. A. Frankovich, A. R. Armitage, and J. W. Fourqurean. 2013. Stoichiometry, growth, and fecundity responses to nutrient enrichment by invertebrate grazers in subtropical turtle grass (Thalassia testudinum) meadows. Marine Biology 160:169-180.

Bartoń, K. 2009. MuMIn: Multi-model inference. R package version 0.12. 2/r18. R Project for Statistical Computing, Vienna, Austria. (Available from: https://cran.r-project.org/web/packages /MuMIn)

Bates, D., M. Maechler, and B. Bolker. 2012. lme4: Linear mixedeffects models using S4 classes (2011). R package version 0.999375-42. R Project for Statistical Computing, Vienna, Austria. (Available from: http://cran.r-project.org/package=lme4)

Bourassa, N., and A. Morin. 1995. Relationships between size structure of invertebrate assemblages and trophy and substrate composition in streams. Journal of the North American Benthological Society 14:393-403.

Bunn, S. E., P. Davies, and T. Mosisch. 1999. Ecosystem measures of river health and their response to riparian and catchment degradation. Freshwater Biology 41:333-345.

Burnham, K. P., and D. R. Anderson. 2001. Kullback-Leibler information as a basis for strong inference in ecological studies. Wildlife Research 28:111-119.

Burnham, K. P., and D. R. Anderson. 2002. Model selection and multimodel inference: a practical information-theoretic approach. Springer, New York.

Butler, N. M., C. A. Suttle, and W. E. Neill. 1989. Discrimination by freshwater zooplankton between single algal cells differing in nutritional status. Oecologia (Berlin) 78:368-372.

Covich, A. P., M. A. Palmer, and T. A. Crowl. 1999. The role of benthic invertebrate species in freshwater ecosystems: zoobenthic species influence energy flows and nutrient cycling. BioScience 49:119-127.

Cross, W. F., J. P. Benstead, P. C. Frost, and S. A. Thomas. 2005. Ecological stoichiometry in freshwater benthic systems: recent progress and perspectives. Freshwater Biology 50:1895-1912.

Cross, W. F., J. P. Benstead, A. D. Rosemond, and J. B. Wallace. 2003. Consumer-resource stoichiometry in detritus-based streams. Ecology Letters 6:721-732.

Cummins, K. W., and M. J. Klug. 1979. Feeding ecology of stream invertebrates. Annual Review of Ecology and Systematics 10: $147-172$.

Davis, J. M., A. D. Rosemond, S. L. Eggert, W. F. Cross, and J. Wallace. 2010. Nutrient enrichment differentially affects body sizes of primary consumers and predators in a detritus-based stream. Limnology and Oceanography 55:2305-2316.
Elser, J. J., W. F. Fagan, R. F. Denno, D. R. Dobberfuhl, A. Folarin, A. Huberty, S. Interlandi, S. S. Kilham, E. McCauley, and K. L. Schulz. 2000. Nutritional constraints in terrestrial and freshwater food webs. Nature 408:578-580.

Fink, P., L. Peters, and E. Von Elert. 2006. Stoichiometric mismatch between littoral invertebrates and their periphyton food. Archiv für Hydrobiologie 165:145-165.

Fink, P., and E. Von Elert. 2006. Physiological responses to stoichiometric constraints: nutrient limitation and compensatory feeding in a freshwater snail. Oikos 115:484-494.

Frazer, G. W., C. Canham, and K. Lertzman. 1999. Gap Light Analyzer (GLA), Version 2.0: Imaging software to extract canopy structure and gap light transmission indices from truecolour fisheye photographs, users manual and program documentation. Simon Fraser University, Burnaby, British Columbia, and the Institute of Ecosystem Studies, Millbrook, New York. (Available from: http://www.caryinstitute.org/science-program/our -scientists/dr-charles-d-canham/gap-light-analyzer-gla)

Fuller, R. L., J. L. Roelofs, and T. J. Fry. 1986. The importance of algae to stream invertebrates. Iournal of the North American Benthological Society 5:290-296.

Guo, F., M. J. Kainz, F. Sheldon, and S. E. Bunn. 2015. Spatial variation in periphyton fatty acid composition in subtropical streams. Freshwater Biology 60:1411-1422.

Guo, F., M. J. Kainz, F. Sheldon, and S. E. Bunn. 2016a. Effects of light and nutrients on periphyton and the fatty acid composition and somatic growth of invertebrate grazers in subtropical streams. Oecologia (Berlin) 181:449-462.

Guo, F., M. J. Kainz, F. Sheldon, and S. E. Bunn. 2016b. The importance of high-quality algal food sources in stream food webs-current status and future perspectives. Freshwater Biology 61:815-831.

Gurevitch, J., L. L. Morrow, A. Wallace, and J. S. Walsh. 1992. A meta-analysis of competition in field experiments. American Naturalist 140:539-572.

Hart, D. D. 1981. Foraging and resource patchiness: field experiments with a grazing stream insect. Oikos 37:46-52.

Hessen, D. O., P. J. Færøvig, and T. Andersen. 2002. Light, nutrients, and P:C ratios in algae: grazer performance related to food quality and quantity. Ecology 83:1886-1898.

Hill, W. R., J. G. Smith, and A. J. Stewart. 2010. Light, nutrients, and herbivore growth in oligotrophic streams. Ecology 91:518-527.

Hillebrand, H., G. de Montpellier, and A. Liess. 2004. Effects of macrograzers and light on periphyton stoichiometry. Oikos 106:93-104.

Hosomi, M., and R. Sudo. 1986. Simultaneous determination of total nitrogen and total phosphorus in freshwater samples using persulfate digestion. International Journal of Environmental Studies 27:267-275.

Jeffrey, S. T., and G. Humphrey. 1975. New spectrophotometric equations for determining chlorophylls a, b, $\mathrm{c} 1$ and $\mathrm{c} 2$ in higher plants, algae and natural phytoplankton. Biochemie and Physiologie der Pflantzen 167:191-194.

Johnson, J. B., and K. S. Omland. 2004. Model selection in ecology and evolution. Trends in Ecology and Evolution 19:101-108.

Kahlert, M., A. T. Hasselrot, H. Hillebrand, and K. Pettersson. 2002. Spatial and temporal variation in the biomass and nutrient status of epilithic algae in Lake Erken, Sweden. Freshwater Biology 47:1191-1215. 
Kohler, S. L. 1984. Search mechanism of a stream grazer in patchy environments: the role of food abundance. Oecologia (Berlin) 62:209-218.

Lamberti, G. A., L. R. Ashkenas, S. V. Gregory, and A. D. Steinman. 1987. Effects of three herbivores on periphyton communities in laboratory streams. Journal of the North American Benthological Society 6:92-104.

Lau, D. C., K. M. Y. Leung, and D. Dudgeon. 2008. Experimental dietary manipulations and concurrent use of assimilationbased analyses for elucidation of consumer-resource relationships in tropical streams. Marine and Freshwater Research 59:963-970.

Lau, D. C., K. M. Leung, and D. Dudgeon. 2009. Are autochthonous foods more important than allochthonous resources to benthic consumers in tropical headwater streams? Journal of the North American Benthological Society 28:426-439.

Liess, A. 2014. Compensatory feeding and low nutrient assimilation efficiencies lead to high nutrient turnover in nitrogenlimited snails. Freshwater Science 33:425-434.

Liess, A., and H. Hillebrand. 2005. Stoichiometric variation in $\mathrm{C}: \mathrm{N}, \mathrm{C}: \mathrm{P}$, and $\mathrm{N}: \mathrm{P}$ ratios of littoral benthic invertebrates. Journal of the North American Benthological Society 24:256269.

Liess, A., and K. Lange. 2011. The snail Potamopyrgus antipodarum grows faster and is more active in the shade, independent of food quality. Oecologia (Berlin) 167:85-96.

Liess, A., K. Lange, F. Schulz, J. J. Piggott, C. D. Matthaei, and C. R. Townsend. 2009. Light, nutrients and grazing interact to determine diatom species richness via changes to productivity, nutrient state and grazer activity. Journal of Ecology 97: 326-336.

Liess, A., A. le Gros, A. Wagenhoff, C. R. Townsend, and C. D. Matthaei. 2012. Landuse intensity in stream catchments affects the benthic food web: consequences for nutrient supply, periphyton $C$ : nutrient ratios, and invertebrate richness and abundance. Freshwater Science 31:813-824.

Lorenzen, C. J. 1967. Determination of chlorophyll and pheopigments: spectrophotometric equations. Limnology and Oceanography 12:343-346.

Mallory, M. A., and J. S. Richardson. 2005. Complex interactions of light, nutrients and consumer density in a stream periphytongrazer (tailed frog tadpoles) system. Iournal of Animal Ecology 74:1020-1028.

McKenny, C. 2005. The diversity of macroinvertebrate grazers in streams: relationships with the productivity and composition of benthic algae. Griffith University, Brisbane, Australia.

McManamay, R. A., J. R. Webster, H. M. Valett, and C. A Dolloff. 2011. Does diet influence consumer nutrient cycling? Macroinvertebrate and fish excretion in streams. Journal of the North American Benthological Society 30:84-102.

Mooney, R. J., E. A. Strauss, and R. J. Haro. 2016. Nutrientspecific foraging by Glossosoma intermedium larvae leads to conspecific case grazing. Freshwater Science 35:874-882.
Mosisch, T. D., S. E. Bunn, and P. M. Davies. 2001. The relative importance of shading and nutrients on algal production in subtropical streams. Freshwater Biology 46:1269-1278.

Muhid, P., T. W. Davis, S. E. Bunn, and M. A. Burford. 2013. Effects of inorganic nutrients in recycled water on freshwater phytoplankton biomass and composition. Water Research 47: 384-394.

Ohta, T., Y. Miyake, and T. Hiura. 2011. Light intensity regulates growth and reproduction of a snail grazer (Gyraulus chinensis) through changes in the quality and biomass of stream periphyton. Freshwater Biology 56:2260-2271.

Qin, P., C. M. Mayer, K. L. Schulz, X. Ji, and M. E. Ritchie. 2007. Ecological stoichiometry in benthic food webs: effect of light and nutrients on periphyton food quantity and quality in lakes. Limnology and Oceanography 52:1728-1734.

Redfield, A. C. 1958. The biological control of chemical factors in the environment. American Scientist 46:205-221.

Sperfeld, E., D. Martin-Creuzburg, and A. Wacker. 2012. Multi ple resource limitation theory applied to herbivorous consumers: Liebig's minimum rule vs. interactive co-limitation. Ecology Letters 15:142-150.

Stelzer, R. S., and G. A. Lamberti. 2001. Effects of N : P ratio and total nutrient concentration on stream periphyton community structure, biomass, and elemental composition. Limnology and Oceanography 46:356-367.

Stelzer, R. S., and G. A. Lamberti. 2002. Ecological stoichiometry in running waters: periphyton chemical composition and snail growth. Ecology 83:1039-1051.

Sterner, R. W., and J. J. Elser. 2002. Ecological stoichiometry: the biology of elements from molecules to the biosphere. Princeton University Press, Princeton, New Jersey.

Sterner, R. W., J. J. Elser, E. J. Fee, S. J. Guildford, and T. H. Chrzanowski. 1997. The light: nutrient ratio in lakes: the balance of energy and materials affects ecosystem structure and process. American Naturalist 150:663-684.

Udy, J. W., and S. E. Bunn. 2001. Short communication: Elevated $\delta \mathrm{N}$ values in aquatic plants from cleared catchments: why? Marine and Freshwater Research 52:347-351.

Udy, J. W., C. S. Fellows, M. E. Bartkow, S. E. Bunn, J. E. Clapcott, and B. D. Harch. 2006. Measures of nutrient processes as indicators of stream ecosystem health. Hydrobiologia 572:89102.

Urabe, J., and R. W. Sterner. 1996. Regulation of herbivore growth by the balance of light and nutrients. Proceedings of the National Academv of Sciences of the United States of America 93:8465-8469.

Wissinger, S. A., G. B. Sparks, G. L. Rouse, W. S. Brown, and H. Steltzer. 1996. Intraguild predation and cannibalism among larvae of detritivorous caddisflies in subalpine wetlands. Ecology 77:2421-2430.

Zuur, A., E. N. Ieno, N. Walker, A. A. Saveliev, and G. M. Smith. 2009. Mixed effects models and extensions in ecology with R. Springer, New York. 